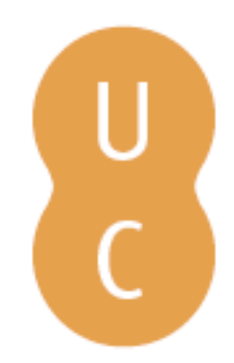

\title{
pommalina
}

\section{Forest fire severity in NW Spain: a case of study}

Autor(es): $\quad$ Fernández-Alonso, J.M.; Vega Hidalgo, J.A.; Jiménez Carmona, E.

Publicado por: Imprensa da Universidade de Coimbra

URL

persistente: URI:http://hdl.handle.net/10316.2/34153

DOI: $\quad$ DOI:http://dx.doi.org/10.14195/978-989-26-0884-6_187

Accessed : $\quad$ 26-Apr-2023 02:59:21

A navegação consulta e descarregamento dos títulos inseridos nas Bibliotecas Digitais UC Digitalis, UC Pombalina e UC Impactum, pressupõem a aceitação plena e sem reservas dos Termos e Condições de Uso destas Bibliotecas Digitais, disponíveis em https://digitalis.uc.pt/pt-pt/termos.

Conforme exposto nos referidos Termos e Condições de Uso, o descarregamento de títulos de acesso restrito requer uma licença válida de autorização devendo o utilizador aceder ao(s) documento(s) a partir de um endereço de IP da instituição detentora da supramencionada licença.

Ao utilizador é apenas permitido o descarregamento para uso pessoal, pelo que o emprego do(s) título(s) descarregado(s) para outro fim, designadamente comercial, carece de autorização do respetivo autor ou editor da obra.

Na medida em que todas as obras da UC Digitalis se encontram protegidas pelo Código do Direito de Autor e Direitos Conexos e demais legislação aplicável, toda a cópia, parcial ou total, deste documento, nos casos em que é legalmente admitida, deverá conter ou fazer-se acompanhar por este aviso. 


\section{ADVANCES IN}

Forest Fire

\section{RESEARCH}

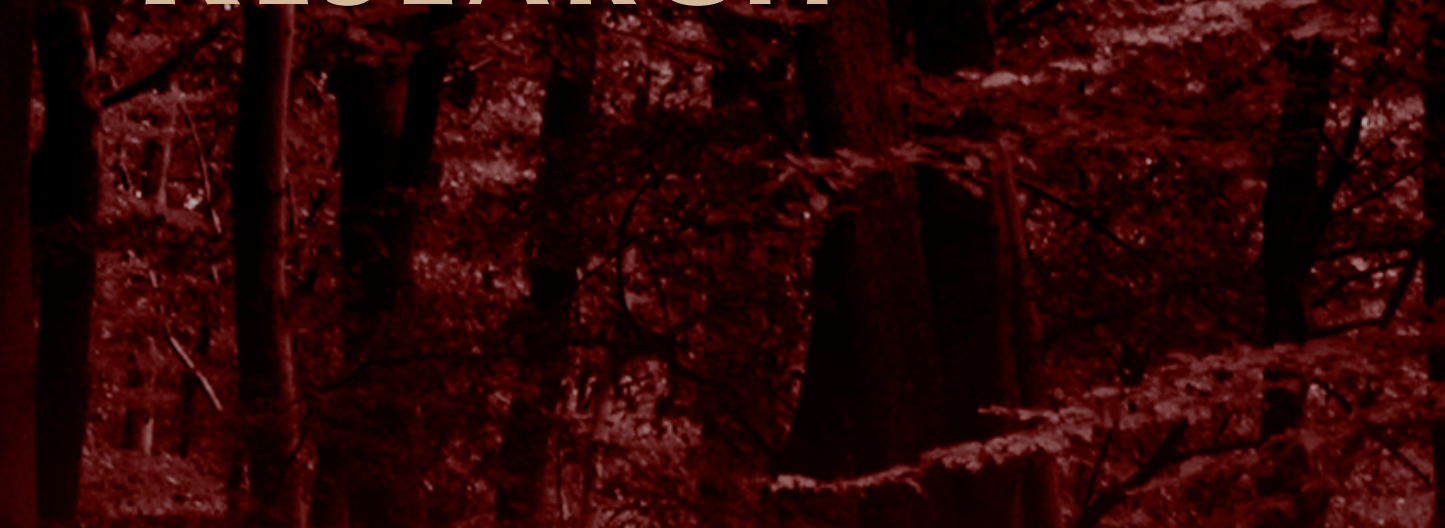

\section{DOMINGOS XAVIER VIEGAS}

\section{EDITOR}




\title{
Forest fire severity in NW Spain: a case of study
}

\author{
Fernández-Alonso, J.M., Vega Hidalgo, J.A., Jiménez Carmona, E. \\ Centro de Investigación Forestal de Lourizán. PO Box 127. 36080, Pontevedra. Spain. \\ txema182@gmail.com
}

\begin{abstract}
Wildfires have become a main forestry concern for pine stands in Galicia (NW Spain). Burned forested areas have patterns of varying burn severity as a consequence of various topographic, vegetation and meteorological factors. Determining the relative importance of these factors is necessary to predict fire severity in the canopy, and therefore, base decisions on fuel management. A spatial study of fire severity for a large wildfire (Oia, Pontevedra) is presented here. Pine stands within the fire were classified according to the fire severity. The effect of meteorological (simulated wind speed and direction), topographic (aspect, slope and combined variables) and canopy fuel structure (LIDAR data) variables was described and then modeled. The presence of high fire severity patches was significantly linked to areas of higher simulated wind speed, to lower height stands and to sunny slopes. Simulated wind speed was the most important variable determining the high intensity areas in the rank order of importance analysis, meanwhile slope and aspect were the second and third most important variables. Canopy structure presented low variability in the studied area, which leads to a low importance in classifying fire severity. Variables evaluating alignment of forces, slope and wind direction, have not been found to be important predictors.
\end{abstract}

Keywords: Random forests model, Pinus pinaster Ait., fire severity, landscape-base

\section{Introduction}

Fire severity reflects the impact of heat pulses aboveground and belowground and it can be assessed as the degree of organic matter consumed (Ryan and Noste 1985, Keeley 2009). Crown fire is considered as extreme fire behavior (Alexander and Cruz in Werth et al 2011) and it is generally considered as one of the highest degrees of fire severity, where tree canopies are killed and needles are consumed (Key and Benson 2006; Lentile et al 2006; Keeley 2009; Holden et al 2009; Lecina et al 2014). That type of stand replacement fires means a challenge for fire managers: they pose an important risk to population and firefighting crews due to difficulty to suppress them. They also are a threat to forest production by removing much or the entire tree canopy in a particular area, and resulting in considerable $\mathrm{C}$ emissions (Jimenez et al 2013). They reset the successional and growth processes of stands and forests (Graham et al, 2004) and can change post-fire dominant vegetation type (Holden, 2009). Moreover that type of fire by consuming all canopy needles leave soil unprotected and prone to post-fire degradation and erosion (Robichaud et al 2000, Alexander et al 2006, Jain and Graham 2004).

Predicting high severity fire is essential to define areas to apply fuel treatments for severity mitigation or forest restoration works (Lentile et al 2006, Holden et al 2009, Amato et al 2013), nevertheless spatial patterns of burn severity over time remain poorly understood to date (Alexander et al 2006; Fernandes et al 2010; Sikkink and Keane 2012). Topography, vegetation and weather vary over space and time and they interact in complex ways to influence fire extent and fire occurrence (Turner and Romme, 1994, Odion et al 2004; Holden et al, 2009). Understanding the relative importance with which these factors contribute to fire severity is critical information for land managers of fire-prone landscapes (Graham et al 2004; Holden et al 2009 Sikkink and Keane 2012) since they may permit to prioritize investments in fuel treatments or to plan suppression tactics.

Despite the relevance of this topic, most of the studies published to date on fire severity are focused in the USA (Turner et al 1994, Lentile et al 2006, Alexander et al 2006, Collins et al 2007, Holden et al 
2009, Dillon et al 2011, Amato et al 2013). Fire severity studies in Europe were carried out mainly in Mediterranean forests (NE Spain) (Broncano and Retana 2004, García-Martín et al 2008, Oliveras et al 2009, Roman-Cuesta et al 2009, Alvarez et al 2013, Lecina-Diaz et al 2014). Most of the studies assess fire severity using medium resolution satellite imagery data (Turner et al 1994, Lentile et al 2006, Collins et al 2007, Holden et al 2009, Dillon et al 2011, Bradstock et al 2010, García-Martín et al 2008, Oliveras et al 2009, Roman-Cuesta et al 2009, Lecina-Diaz et al 2014), whereas less studies used a field sampling-based approach (Broncano-Retana 2004, Holden 2009, Fernandes et al 2010, Alvarez et al 2013). Information from satellite imagery allows assessing fire severity patterns across a large scale and over time. This is useful to reflect the complexity of the interaction among topography, vegetation cover and weather (Amato et al 2013). However field data -based studies supply with more detailed information on that interaction and at finer scale.

In Galicia (northwestern Spain), a territory of about 30,000 km2, more than 10,000 fires occur annually (D.X. Montes 2010). That represents about than half of fires in Spain (MARM 2010). In that area, suitable conditions for biomass growth, summer drought and abundant ignition sources coincide (Vazquez 2006; Moreno and Chuvieco 2013), favoring high severity fires. Most of these fires occur in very continuous and productive conifer stands frequently resulting in stand replacement crown fires. These fires cause important economical losses and severe ecological impacts. Given the dominance of rainy climate and the steep terrain in the area, the main undesirable post-fire consequence is the soil erosion. This problem is more dramatic in crown fire-affected areas where soil losses measured following this type of fire in Galicia are considered the highest rates after wildfire in the Southern Europe, requiring costly rehabilitation treatments (Fernandez et al 2011; Vega et al 2014).

Despite of the tremendous impact of the high severity fires in Northwestern Iberian Peninsula, not a single study has been carried out on this topic in that area. Therefore, we considered essential to gain knowledge in how fine scale variables, used as inputs from empirical fire behavior models (Rothermel 1972, Rothermel 1991, Van Wagner 1977, Cruz et al 2004) and their spatial and temporal variability during the occurrence of a wildfire, can affect the severity patterns in a landscape scale. In the present paper we used fire related variables (topography, weather and fuel structure parameters) to evaluate their importance on high severity fire patterns in Oia fire in Galicia. More specifically we addressed: (i) assessing the differences of these variables between high-severity crown fire areas and low severity areas (ii) fitting statistical models to determine their capability to predict high-severity fire occurrence and the relative importance of each predictor variable.

\section{Methods}

\subsection{Study area}

Our research focused on the Oia wildfire (area > 500 ha) occurred during the summer of 2013 in the coastal area of Galicia (Northwestern Spain) (Fig 1). This wildfire affected mainly Pinus pinaster Ait. (maritime pine) pole-size stands.

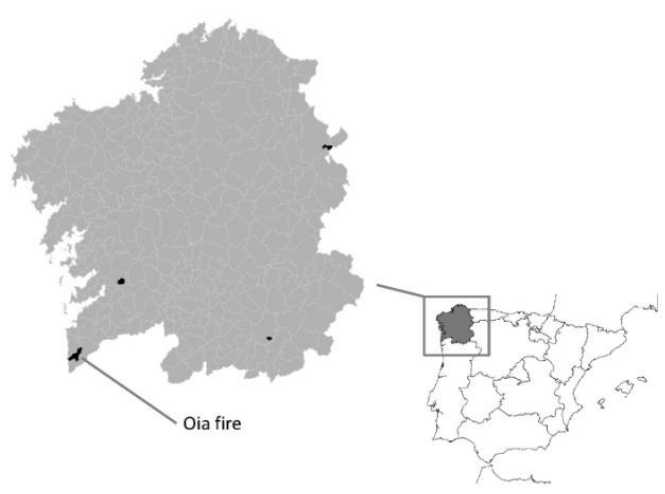

Figure 1. Location of the study area, in Galicia (NW Spain) 
The Oia fire occurred in the municipalities of Oia and O Rosal (Pontevedra province). The elevation of the study area ranged from 30 to $515 \mathrm{~m}$. The aspect was generally southeast, with slopes between 0 and $65 \%$. Maritime pine and Eucalyptus globulus Labill. (blue gum) were the dominant tree species and the main shrub species were Ulex europaeus L., Pteridium aquilinum (L.) Kuhn, and Pterospartum tridentatum (L.) Wilk. The fire was human-caused and started in $26^{\text {th }}$ August 2013. It was brought under control two days after the ignition. It burned 1810 ha. According to Spain Lithological Map 1/50.000 (http://www.igme.es/internet/cartografia/cartografia/magna50.asp, accessed on $21^{\text {st }}$ June 2014), the soils in this area are developed from schist, slates and granite.

Meteorological conditions during the wildfire are presented in Table 1.

Table1 - Meteorological conditions during the wildfire. Variables from Canadian Forest Fire Weather Index (Van Wagner 1987): FFMC: Fine Fuel Moisture Code; DMC: Duff Moisture Code; DC: Drought Code; ISI: Initial Spread Index; BUI: Buildup Index; FWI: Fire Weather Index. Data from meteorological station located at $4 \mathrm{~km}$ from the burned area (Meteogalicia, Xunta de Galicia)

\begin{tabular}{lcc}
\cline { 2 - 3 } Variable & $26^{\text {th }}$ August & $28^{\text {th }}$ August \\
\hline Temperature $\left({ }^{\circ} \mathrm{C}\right)$ & $18.8(13.4-26.1)$ & $20.6(15.3-26.7)$ \\
Relative humidity $(\%)$ & $63.3(44-85)$ & $61.6(45-79)$ \\
Wind speed $(\mathrm{km} \mathrm{h}-1)$ & $20.4(5.4-33.3)$ & $17.7(6.1-33.8)$ \\
Wind gusts $(\mathrm{km} . \mathrm{h}-1)$ & $36.2(15.1-53.6)$ & $33.3(11.7-56.7)$ \\
Wind direction $\left({ }^{\circ}\right)$ & 50 & 76 \\
FFMC & 88 & 88 \\
DMC & 87 & 87 \\
DC & 512 & 512 \\
ISI & 5 & 5 \\
BUI & 122 & 122 \\
FWI & 21 & 23 \\
\hline
\end{tabular}

\subsection{Field sampling and spatial data}

Wind speed and direction, fuelbed load and structure, slope, fuel moisture content, distance from the surface fuelbed to the lower limit of the canopy stratum and crown bulk density are the input variables determining crown fire occurrence (Van Wagner 1977, Cruz et al 2004).

Fieldwork was carried out in the following weeks after the fire. Areas affected by crown fire were visually identified as the patches where the crown fine fuel consumption was complete. The perimeters were tracked using a Trimble Juno 5B GNSS to delimit these areas from where tree crown were totally or partially scorched in the same stand. The areas of interest for the present study were delimited in a Geographic Information System (GIS) as continuous stands where the high-severity fire (crown fire) occurred and surface or low severity fire was observed in the surrounding area. In this way, two contrasted fire severity levels were considered: high and low.

A grid of $100 \mathrm{~m}$ was overlaid on a map of the areas of interest. The starting sample point was randomly chosen and 41 sample points were selected. Circular plots of $10 \mathrm{~m}$ radius were established on each point. In each plot, all trees with diameter at breast height $(\mathrm{Dbh})>5 \mathrm{~cm}$ were tagged. Diameter at breast height, total height and post-fire crown base height were measured for each tagged tree. Descriptive characteristics of the plots are presented in table 2. Fire direction was determined observing the char patterns on the tree trunks and the stuck pine needles. 
Table2. Mean characteristics and range of monitored plots. Dbh: diameter at breast height; $\mathrm{Ht}$ : total height; $\mathrm{CBH}$ : crown base height, G: basal area. Minimum and maximum observed values of means per plot between brackets

\begin{tabular}{lccccc}
\hline Type of fire & Density $\left(\right.$ trees.h $\left.^{-1}\right)$ & $\mathrm{Dbh}(\mathrm{cm})$ & $\mathrm{Ht}(\mathrm{m})$ & $\mathrm{CBH}(\mathrm{m})$ & $\mathrm{G}\left(\mathrm{m}^{2} \cdot \mathrm{ha}^{-1}\right)$ \\
\hline High-severity & $1364(265-2487)$ & $16.4(11.2-22.9)$ & $12.4(8.8-15.8)$ & $6(1.9-9.7)$ & $29.4(9.9-56.7)$ \\
Low-severity & $881(368-1741)$ & $21.5(14.9-36.6)$ & $15.3(9.4-29.6)$ & $8.4(2.5-23.1)$ & $32.4(7.9-53.8)$ \\
\hline
\end{tabular}

Given the landscape-scale and spatial characteristics of a large wildfire, we used the methodology proposed by Stratton et al (2006) for wildland fire spatial analysis of the fire environment (weather, fuel, topography) variables.

Grid-based digital elevation model (DEM) at horizontal resolution of $25 \mathrm{~m}$ was obtained for the study area from the Spanish Geographic National Institute (http://www.ign.es/ign/layoutIn/modeloDigitalTerreno.do, accessed on 21st June 2014). The DEM was used to calculate the slope and aspect (topography variables) within each fire digital perimeter in ArcGIS v. 9.3 (ESRI 2008).

The same DEM was utilized to simulate the wind fields within the fire perimeters with WindNinja (Forthofer, 2007). WindNinja is a mass-consistent fluid flow dynamics models that estimates the modifying effects of topography on synoptic winds. Although presumably local wind field could be significantly affected by the fire itself, obtaining direct information on wind field within fire perimeter was not an operational option. Wind and temperature data were obtained from Meteogalicia weather stations network (http://www2.meteogalicia.es/galego/observacion/estacions/estacions.asp, accessed on June 21, 2014). The two closest weather stations were selected to supply with the information necessary for the corresponding wind simulations. Characteristics of weather stations are shown in table 3. Wind simulations were made for the wildfire at ignition time and at different moments of the fire run by dividing burned area in function of the approximated position of the fire front, by using the information provided by the suppression crews. Vector files (point geometry) containing wind speed and wind direction were generated and clipped for the study area.

Table3 - Characteristics of weather stations used in the wind simulation (Meteogalicia, Xunta de Galicia)

\begin{tabular}{ccc}
\hline Station name & Elevation $(\mathrm{m})$ & Distance to study area $(\mathrm{km})$ \\
\hline Castro Vicaludo & 440 & 4 \\
Aloia & 480 & 15 \\
\hline
\end{tabular}

A database was created including topography (aspect and slope) and simulated wind variables (wind speed and direction) for each pixel within the fire perimeter. With the aim of evaluating if the concurrent effects of the simulated wind and slope is determinant for the occurrence of high-severity crown fire in the same way it is for fire behavior (Weise and Biging, 1997) two combined variables were calculated and included:

a) Terrain slope in the wind direction (fig 2), ranging from positive value of maximun slope (wind vector aligned with upslope vector) to negative value of maximum slope (wind aligned downslope) and

b) the difference between upslope direction and wind direction (fig 3) vectoring as described in Rothermel (1983), where $0^{\circ}$ is complete alignment of slope and wind blowing upslope, and $180^{\circ}$ means alignment of slope and wind blowing downslope. 

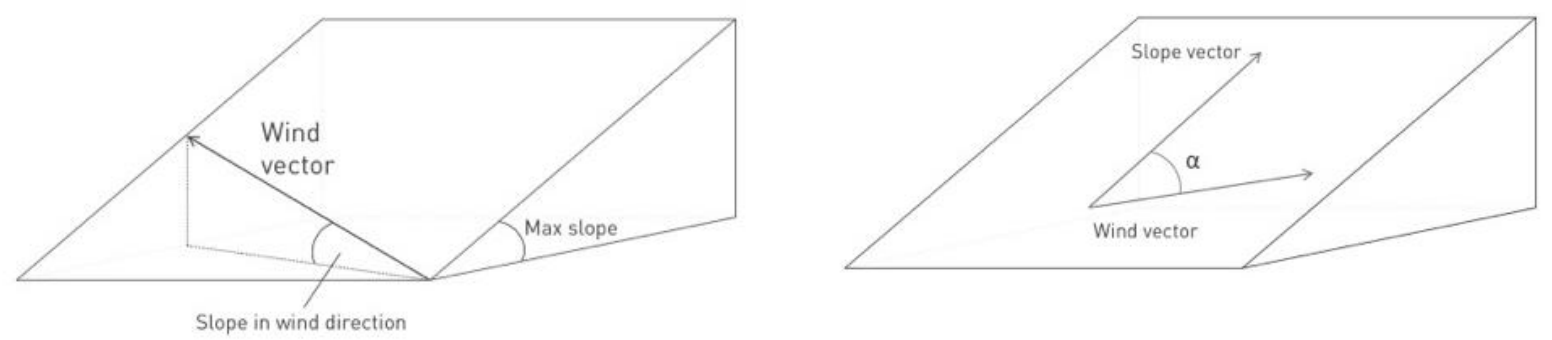

Figure 2 and 3. Sketches of: slope in wind direction calculation, referenced to maximum slope (left) and degree of alignment between slope and wind vector ( $\alpha$ ), referenced to the slope vector (maximum slope) (right)

National Aerial Ortophoto Program (PNOA) LIDAR data (http://www.ign.es/PNOA/presentacion.html) was used to account for the effect of vegetation structure on fire severity. Light Detection and Ranging (LIDAR) technology has proven its capability to measure canopy and surface fuel structure and to generate landscape-scale maps of these variables (Riaño et al 2004, Andersen et al 2005, Skowronski et al 2011, Mutlu et al 2008,van Aardt et al 2011, Jakubowski et al 2013; Gonzalez-Olabarría et al 2012). In fact, these studies have shown that LIDAR data allow to fit models to estimate variables directly linked with crown fire behavior, such as canopy bulk density (CBD), crown fuel load (CFL), canopy base height $(\mathrm{CBH})$, and also understory stratum. In this area of study the LIDAR flights were carried out in the year 2009. Values of the laser height distribution (mean, minimum, maximum, mode and percentiles) and canopy cover above $2 \mathrm{~m}$ were added to the statistical analysis as a potential predictor for fire severity on canopy, given the above relationship between these variables and the vegetation variables that drive crown fire initiation $(\mathrm{CBH}$, surface fuel structure) and spread (CFL, CBD).

\subsection{Statistical analysis}

Two statistical tests were applied to the variables distribution to assess significant differences between the two severity categories considered. The Kruskal-Wallis one-way analysis of variance was used to examine significant differences for each potential continuous variable. Fisher's Exact Test was applied to the contingency table to examine the significance of the association between fire severity and aspect class.

Random Forests (RF) (Breiman, 2001) is a variant of Classification and Regression Trees (CART). This technique is an ensemble method that fits many classification trees to a data set and then combines the predictions from all the trees. Approximately $66 \%$ of the data are used in a classification tree with the remaining data used as a validation data set (called out-of-bag observations). An estimate of the error rate is obtained based in this out-of-bag, or OOB, data. RF has shown its power in the analysis of ecological data in a landscape base in the Cutler et al (2007) study, in which RF showed higher classification accuracy than four other commonly statistical classifiers. Holden et al (2009) used Random Forest to assess the ability of landscape variables to predict severe fire occurrence and Pierce et al (2012) also used RF for modeling and mapping four canopy fuel variables at a landscape level. We used this statistical approach to assess the ability of topography, fuel and wind variables to predict fire severity on forest canopy layer. We used the Random Forest Package developed for R (R Core Team, 2013) by Liaw and Weiner (2002). A first RF model was adjusted containing weather and topographic variables (6 variables) and all the LIDAR variables (67 variables) into the dataset to compare the goodness-of-fit of each model and to select the most relevant variables. For a suitable evaluation of the variable importance, multicollinearity between variables was analyzed using the Pearson's correlation coefficient: the threshold of 0.75 was applied as criteria for removal any of the correlated variables. The final RF models were adjusted with the dataset containing the remaining variables (6 or 7 variables). Sampsize option was used to account for the lack of balance in the datasets. 
High-severity observations were less than the low-severity ones, so sampsize was set up in order to RF select the same number of observations for each type of fire severity by randomly decreasing the sampling size of scorched fire observations.

Model error stabilized after 2000 bootstrap replicates. The $\mathrm{m}$ parameter (number of predictors randomly selected at each tree node as potential variables to base the split on) was optimized with 3 of the 6 explanatory variables. Variance plots were used to identify the relative strength of each predictor variable.

\section{Results}

\subsection{Variables related to fire severity}

Mean value of terrain slope was higher in low severity-affected stands than in high severity patches (table 4), but the difference was less than 4\%. Mean wind speed was higher for high-severity patches than for low-severity ones, with a difference of $2.2 \mathrm{~km} . \mathrm{h}-1$ between them. Minimum wind speed values were also higher for high-severity patches. Mean values for simulated wind direction were very close between fire severity levels: 66 and 67 degrees for high and low severity respectively. Mean values for slope in wind direction were very close, with a difference of $2.4 \%$ between fire severity levels and very similar ranges for both. Angle between maximum slope and wind direction showed a higher mean value for high severity patches, 109 degrees, and the difference with low severity patches was 9 degrees.

Kruskal-Wallis one-way analysis of variance test determined that only the distribution of terrain slope, wind speed, and angle between maximum slope direction and wind direction values were significantly different $(\mathrm{p}<0.05)$ between fire-severity levels.

Table 4- Mean and range for topography and weather variables values in the studied area. SD = standard deviation. Obs = number of observations

\begin{tabular}{|c|c|c|c|c|c|c|c|}
\hline Fire type & $\begin{array}{l}\text { Statist } \\
\text { ics }\end{array}$ & $\begin{array}{c}\text { Slope } \\
(\%)\end{array}$ & $\begin{array}{c}\text { Wind Speed } \\
(\mathrm{km} / \mathrm{h})\end{array}$ & $\begin{array}{c}\text { Wind } \\
\text { direction }\left({ }^{\circ}\right)\end{array}$ & $\begin{array}{l}\text { Slope in wind } \\
\text { direction }(\%)\end{array}$ & $\begin{array}{l}\text { Max.slope-wind } \\
\text { direction }\left({ }^{\circ}\right)\end{array}$ & Obs \\
\hline \multirow{4}{*}{$\begin{array}{l}\text { High } \\
\text { severity }\end{array}$} & Min. & 4.0 & 12.6 & 55 & -44.7 & 1 & \multirow{4}{*}{3335} \\
\hline & Max. & 60.6 & 27.6 & 81 & 58.7 & 180 & \\
\hline & Mean & 26.4 & 20.3 & 66 & -3.4 & 109 & \\
\hline & SD & 12.5 & 2.5 & 4 & 18.1 & 45 & \\
\hline \multirow{4}{*}{$\begin{array}{l}\text { Low } \\
\text { severity }\end{array}$} & Min. & 0.3 & 8.7 & 53 & -48.7 & 0 & \multirow{4}{*}{7781} \\
\hline & Max. & 65.8 & 27.6 & 109 & 65.5 & 179 & \\
\hline & Mean & 30.2 & 18.1 & 67 & -1.0 & 100 & \\
\hline & SD & 14.7 & 3.1 & 8 & 23.6 & 48 & \\
\hline
\end{tabular}

Table 5 shows the observed percentage distribution, in aspect class, for each severity level. High severity fire was significantly more frequent in S, SE and SW aspect classes (sunny slopes) (Fisher's Exact Test; p-value < 0.01). Conversely, E, N, NE and NW aspect classes showed more low-severity points.

Table 5- Percentage of pixels by aspect class in the studied area. Obs = number of observations

\begin{tabular}{lllllllllll}
\hline Fire type & Flat & N & NE & NW & E & S & SE & SW & W & Obs \\
\hline High-severity & $0.0 \%$ & $1.8 \%$ & $2.7 \%$ & $7.2 \%$ & $7.5 \%$ & $20.9 \%$ & $26.9 \%$ & $16.1 \%$ & $17.0 \%$ & 335 \\
Low-severity & $0.0 \%$ & $5.0 \%$ & $7.0 \%$ & $14.3 \%$ & $9.5 \%$ & $15.9 \%$ & $19.1 \%$ & $9.6 \%$ & $19.6 \%$ & 781 \\
\hline
\end{tabular}




\subsection{RF model}

Table 6 shows the statistics for the only relevant LIDAR variable in classifying high severity fire after fitting the RF model. According the RF classification, maximum elevation (Elev max) of LIDAR pulse appeared to be the only important variable, and it was significantly different (Kruskal-Wallis test, $\mathrm{p}<0.05)$ between high and low severity areas. Mean value of LIDAR maximum elevation was higher for low severity patches than for high severity ones.

\begin{tabular}{llllll}
\hline Variable & Type of fire & Mean & SD & Minimum & Maximum \\
\hline \multirow{2}{*}{ Elev max } & High-severity & 8.00 & 3.27 & 0.61 & 18.93 \\
& Low-severity & 9.27 & 4.54 & 0.46 & 33.59 \\
\hline
\end{tabular}

Table 6. LIDAR variable used for determining severity crown fire occurrence. Elev max = maximum elevation of LIDAR pulse.

Table 7 shows the out-of-bag (OOB) estimate of error rate for the classification of fire severity. Total OOB estimate was $18.46 \%$. For high severity estimations the number of misclassified observations was $23.72 \%$.

Table 7. Confusion matrix for the Random Forests model predicting severity crown fire occurrence in each severity level. Obs = observed fire, Pred = predicted fire, $O O B=$ out-of-bag estimation of error.

\begin{tabular}{|c|c|c|c|}
\hline \multicolumn{4}{|c|}{ Pred. } \\
\hline Obs. & Low-severity & High-severity & \\
\hline Low-severity & 700 & 137 & $16.37 \%$ \\
\hline High-severity & 79 & 254 & $23.72 \%$ \\
\hline & & OOB estimate: & $18.46 \%$ \\
\hline
\end{tabular}

Figure 4 shows rank orders of variable importance for the RF model. The most important variables classifying fire severity are at the top of the y-axis. A weather variable, wind speed, was the most important one for this fire. Slope and aspect class, both topography variables, were the second and the third most important variables. Maximum elevation of LIDAR pulse, a fuel variable, was the less important variable in classifying fire severity.

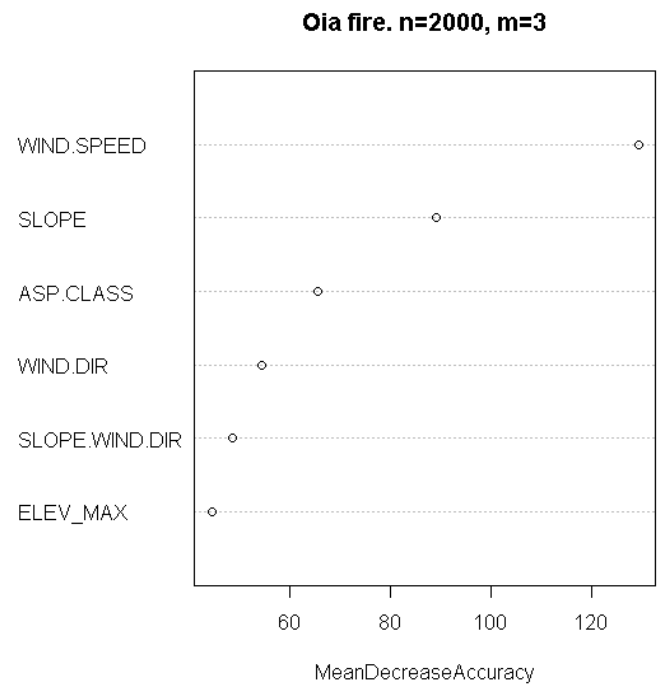

Figure 4. RF variable importance rank plot for the studied area. The most important variables predicting crown fire severity are at the top of the $y$-axis. $n=$ number of trees in the $R F$ model and $m=n u m b e r$ of predictors randomly selected at each tree node as potential variables to base the split on. 


\section{Discussion and conclusions}

\subsection{Variables related to fire severity}

The effect of slope on severity is dissimilar in literature. Some authors have found positive correlations between fire severity and slope (Jimerson and Jones 2003, Alexander et al 2006, Holden et al, 2009). Contrarily, Bradstock et al (2010) found a negative correlation between fire severity and slope, which is explained by the authors as a possible effect of rocks outcrops, common in slopes, lowering the fire intensity. Although the slope was significantly different between severity levels in our study, difference in mean values was less than $4 \%$, which we consider not having a large effect on fire behavior.

Few studies have taken into account the effect of wind speed on fire severity and all of them have followed different approaches to the one we used in this study. Dillon et al (2011) used mean and maximum values of wind speed for a 10-days period starting on the detection date of each fire and number of days with wind speed above 20 miles/hour. These wind variables were positively related to fire severity in only one of the six studied regions. Collins et al (2007) used mean wind speed values for each burning period in two fires and they observed contrasting associations between wind speed and fire severity. Bradstock et al (2010) found a positive association between high severity and extreme weather, variable that includes the effect of wind speed. Our approach, in which wind speed was simulated taking into account the effect of topography, seems hardly comparable. However, the positive association we found between high severity fire and wind speed seems consistent with the results in the above studies.

Alignment of wind and slope did not seem essential for high severity occurrence. Statistical difference was found for the variable angle between slope and wind direction between fire severity levels. Despite of these results, difference for mean values between fire levels was only 9 degrees. This scarce difference between fire severity levels may point out that was not determinant for high severity occurrence in the studied area.

Studies in fire severity have found dissimilar results regarding the effect of aspect on fire severity. Weatherspoon and Skinner (1995) and Alexander et al (2006) have found that patterns of severity were associated to the aspect, underlining that south-facing slopes or flat terrains tended to burn with higher severity than other aspects. Holden et al (2009) found that at lower elevations, north-facing slopes were proner to have high intensity fire likely because a higher vegetation growth than in south-facing slopes, whereas at higher elevations solar insolation would increase drying of surface fuels in southface slopes, which are associated to higher burn severity. Dillon et al (2011) also found north-facing slopes to focus high severity fires for five of six ecoregions studied. Nevertheless, in the Pacific ecoregion the probability of high severity fire was highest in the warmest aspects, which may be explained because aspect is not a limiting factor for productivity in these areas with high precipitation. In our study, given that the elevations were relatively low and the annual rainfall is high, we consider that the fuel availability is not limited by the aspect. Summer drought is common during the fire season in Galicia, which could act drying the sunny slopes and leading to an increased probability of severe fire in those aspects.

ELEV_MAX variable was positively correlated to canopy height (Andersen et al, 2005), so looking at table 4 one can say that, under the same under conditions, high severity fire tended to occur more frequently in lower (i.e younger) stands. Studies in maritime pine stands for the same area (Jimenez et al 2013, Fernandez-Alonso et al 2013, Gomez-Vazquez et al 2013) have shown that there is a positive correlation between mean stand height or dominant height and canopy base height (CBH). Thus, higher stands may have also higher $\mathrm{CBH}$ values and therefore, lower possibilities of crown fire occurrence.

\subsection{RF model}

Despite of the correction for the unbalanced dataset, since the number of high severity observations was lower than low severity observations, results showed that RF had more difficulties to correctly 
classify high severity observations. A possible explanation for such phenomenon is that less information on high severity occurrence was available for RF, which complicated its correct classification. Anyway, RF model was a useful tool to determine which variables were related with high severity occurrence and which was the relative importance of each of them.

This case of study was a good example of wind-driven fire. Meteorological station data (not shown) presented a constant wind conditions during the fire and the fire shape (Anderson, 1983) was narrow and elongated, with an approximated length to width ratio of $4: 1$. Information provided by fire fighting services described the fire as driven by strong winds, with high spotting activity and the most of the fire runs occurring during the first night. Our results seem compatible with these observations. High wind gusts were observed for the closest weather station and mean wind speed was considerably high during the fire. Under these conditions it seems reasonable that wind speed played a determinant role in the fire behavior in this area and, hence, controlling fire severity, as it was shown by the RF model. Fuel variables were the last in the importance ranking determining high severity occurrence for this fire. A possible explanation is the homogeneity of canopy fuel structure within this area: mean values for LIDAR maximum elevation of canopy layer were very close between fire severity levels. This fact supports that studied stands were considerably similar for this fire and canopy structure did not play an important role in high severity occurrence.

Regardless of the favorable results, some limitations of our approach are evident. We used driver variables of fire behavior to estimate fire severity, but we acknowledge that fire behavior models do not necessarily provide good predictions of fire severity (Alexander et al 2006). Nevertheless, studied variables here are well-known for affecting fire intensity, and in the case of a tree stand, a higher intensity can lead to crown activity and to a higher canopy fuels consumption (Alexander, 1982).

The effect of wind speed explaining high severity occurrence must be taken with caution. Windninja simulation only accounts for the effects of topography, but obviously there was an interaction between fire and the atmosphere surrounding fire that affects the crown fire activity (Coen et al 2004). In cases with moderate wind conditions, these interactions may become more important for fire behavior than local winds as convective plume created by the fire modifies notably its surrounding atmosphere (Potter, 2012) and fire -induced turbulence can be critical to understand apparently inexplicable fire behavior (Seto et al. 2013).

Results regarding the variable importance should be taken in the context of the studied area. In our study most of the stands had similar ages and all of them were pure and even-aged, which means that canopy fuel structure was quite similar within each stand. Moreover, fuel treatments aimed at reducing fire severity on canopy were not identified in the studied area. Under those conditions is understandable that weather variables were the most important predictors of high severity in two of the fires because their higher variability within the perimeter.

However our results seem reasonable and consistent with the current knowledge on fire severity phenomenon. In despite of the limitations of the wind simulation approach used, wind speed emerged as the most important variable predicting high severity occurrence. That agrees with the central role the current models give to wind in fire intensity and rate of spread, and accordingly, to fire severity. Our results also suggest that slope and aspect class, the latter likely as a surrogate of fuel moisture, seemed to play an important role in determining crowning occurrence and fire severity on canopy. Having into account the rate of accuracy of the RF model, this methodology may be helpful for fire managers to delimitate and plan fuel treatment works for severity mitigation, in areas where fire events recur under a fixed synoptic wind condition and post hoc case study

\section{Acknowledgments}

The research was funded by the agreement between the Spanish Ministry of Agriculture and INIA, Project RTA2009-0153- C03-01. 


\section{References}

Alexander JD, Seavy NE, Ralph CJ, Hogoboom B (2006) Vegetation and topographical correlates of fire severity from two fires in the Klamath-Siskiyou region of Oregon and California. Int J Wildland Fire 15: 237-245

Alexander ME (1982) Calculating and interpreting forest fire intensities. Canadian Journal of Botany 60, 349-357.

Alvarez A, Gracia M, Castellnou M, Retana J (2013) Variables That Influence Changes in Fire Severity and Their Relationship with Changes Between Surface and Crown Fires in a Wind-Driven Wildfire. For Sci 59: 139-150.

Amato, V.J.W.; Lightfoot, D.; Stropki, C.; Pease, M. 2013. Relationships between tree stand density and burn severity as measured by the Composite Burn Index following a ponderosa pine forest wildfire in the American Southwest. Forest Ecology and Management 302: 71-84.

Andersen, H. E., McGaughey, R. J., \& Reutebuch, S. E. (2005). Estimating forest canopy fuel parameters using LiDAR data. Remote Sensing of Environment, 94, 441-449.

Anderson, H.E. 1983. Predicting wind-driven wildland fire size and shape. USDA For. Serv. Res. Pap. INT-305.

Bradstock RA, Hammill KA, Collins L, Price O (2010) Effects of weather, fuel and terrain on fire severity in topographically diverse landscapes of south-eastern Australia. Landsc Ecol 25: 607619.

Breiman, L. "Random forests, 2001" Machine Learning, vol. 45, no. 1, pp. 5-32

Broncano MJ, Retana J (2004) Topography and forest composition affecting the variability in fire severity and post-fire regeneration occuring after a large fire in the Mediterranean basin. Int $\mathrm{J}$ Wildland Fire 13: 209-216

Coen, J., S. Mahalingam, and J. Daily (2004), Infrared imagery of crown-fire dynamics during FROSTFIRE, J. Appl. Meteorol., 43,1241-1259.

Collins BM, Kelly M, van Wagtendonk JW, Stephens SL. 2007. Spatial patterns of large natural fires in Sierra Nevada. Landsc Ecol 22:545-57

Cruz MG, Alexander ME, Wakimoto RH (2004) Modeling the likelihood of crown fire occurrence in conifer forest stands. Forest Science 50, 640-658.

Cutler, D.R., Edwards Jr., T.C., Beard, K.H., Cutler, A., Hess, K.T., Gibson, J., Lawler, J.J., 2007. Random forests for classification in ecology. Ecology 88 (11), 2783-2792

Dillon, G.K., Holden, Z.A., Morgan, P., Crimmins, M.A., Heyerdahl, E.K., Luce, C.H., 2011. Both topography and climate affected forest and woodland burn severity in two regions of the western US, 1984-2006. Ecosphere 2 (12).

D.X. Montes 2010. Memoria do Plan de Prevención e Defensa contra Incendios Forestais de Galicia. Consellería de Medio Rural. Xunta de Galicia. Santiago de Compostela

Fernandes, P.M., Luz, A., Loureiro, C., 2010. Changes in wildfire severity from maritime pine woodland to contiguous forest types in the mountains of northwestern Portugal. Forest Ecology and Management 260, 883-892.

Fernández, C.; Vega J.A.; Jiménez, E. ; Fonturbel, M.T, (2011), Effectiveness of three post-fire treatments at reducing soil erosion in Galicia (NW Spain). International Journal of Wildland Fire . (20) p. 104-114.

Fernández-Alonso, J.M.; Alberdi, I.; Alvarez-González, J.G.; Vega, J.A.; Cañellas, I.; Ruiz-González, A.D., (2013), Canopy fuel characteristics in relation to crown fire potential in pine stands: analysis, modelling and classification. European Journal of Forest Research. (132) p. 363-377.

Forthofer J.M., 2007. Modeling wind in complex terrain for use in fire spread prediction. Masters thesis. Colorado State University, USA. 123 pp. 
García-Martín, A., Pérez-Cabello, F., de la Riva, J.R., Montorio, R., 2008. Estimation of crown biomass of Pinus spp. from Landsat TM and its effect on burn severity in a Spanish fire scar. IEEE Journal of Selected Topics in Applied Earth Observations and Remote Sensing 1, 254-265.

Gómez-Vázquez I, Crecente-Campo F, Diéguez-Aranda U, Castedo- Dorado F (2013) Modelling canopy fuel variables for Pinus pinaster Ait. and Pinus radiata D. Don in northwestern Spain. Ann Sci 70: 161-172

Gonzalez-Olabarria, J.R.; Rodrigez, F.M.; Fernandez-Landa, A.; Mola-Yudego, B. (2012): Mapping fire risk in the Model Forest of Urbión based on airborne LiDAR measurements. Forest Ecology and Management. 282: 149-156

Graham, Russell T.; McCaffrey, Sarah; Jain, Theresa B. (tech. eds.) 2004. Science basis for changing forest structure to modify wildfire behavior and severity. Gen. Tech. Rep. RMRS-20 GTR-120. Fort Collins, CO: U.S. Department of Agriculture, Forest Service, Rocky Mountain Research Station. $43 \mathrm{p}$

Holden, Z.A., P. Morgan, and J.S. Evans. 2009. A predictive model of burn severity based on 20-year satellite-inferred burn severity data in a large southwestern U.S. wilderness area. Forest Ecology and Management. 258 (11), 2399-2406.

Jakubowski, M.K.; Guo, Q.; Kelly, M. Tradeoffs between lidar pulse density and forest measurement accuracy. Remote Sens. Environ. 2013, 130, 245-253, doi:10.1016/j.rse.2012.11.024.

Jiménez, E.; Vega, J.A.; Ruiz-González, A. D., Guijarro, M.; Alvarez-González, J. G.; Madrigal, J.; Cuiñas, P.; Hernando, C.; Fernández-Alonso, J.M., (2013), Carbon emissions and vertical pattern of canopy fuel consumption in three Pinus pinaster Ait. active crown fires in Galicia (NW Spain).. Ecological Engineering . (54) p. 202-209.

Jimenez, E., J. A. Vega, J. M. Fernandez-Alonso, D. Vega-Nieva, J. G. Alvarez-Gonzalez, and A. D. Ruiz-Gonzalez. 2013. Allometric equations for estimating canopy fuel load and distribution of polesize maritime pine trees in five Iberian provenances. Canadian Journal of Forest Research, v. 43, no. 2, p. 149-158. 10.1139/cjfr-2012-0374

Jimerson, T.M., Jones, D.W. (2003). Megram: Blowdown, Wildlife, and the Effects of Fuel Treatment. T. T. R. Station. Miscellaneous Report No. 13, 55-59.

Keeley, J.E., 2009. Fire intensity, fire severity and burn severity: a brief review and suggested usage. International Journal of Wildland Fire 18, 116-126.

Key CH, Benson NC (2006) Landscape assessment (LA): sampling and analysis methods. In FIREMON: Fire Effects Monitoring and Inventory System. General Technical Report RMRSGTR-164-CD. USDA Forest Service, Rocky Mountain Research Station, Fort Collins, Co.

Lecina-Diaz J, Alvarez A, Retana J (2014) Extreme Fire Severity Patterns in Topographic, Convective and Wind-Driven Historical Wildfires of Mediterranean Pine Forests. PLoS ONE 9(1): e85127. doi:10.1371/journal.pone.0085127

Lentile LB, Holden ZA, Smith AMS, Falkowski MJ, Hudak AT, et al. (2006) Remote sensing techniques to assess active fire characteristics and post-fire effects. Int J Wildland Fire 15: 319345.

Liaw, A., Weiner, M., 2002. Classification and regression by Random Forests. R News 2, 18-22.

MARM (2010) Anuario de estadı'stica. Ministerio de Medio Ambiente y Medio Rural y Marino, Madrid

Moreno M. Vanesa, Chuvieco Emilio (2013) Characterising fire regimes in Spain from fire statistics. International Journal of Wildland Fire 22, 296-305.

Mutlu, M., Popescu, S. C., Stripling, C., \& Spencer, T. (2008). Assessing surface fuel models using lidar and multispectral data fusion.Remote Sensing of Environment,112, 274-285.

Oliveras I, Gracia M, More' G, Retana J (2009) Factors influencing the pattern of fire severities in a large wildfire under extreme meteorological conditions in the Mediterranean basin. Int J Wildland Fire 18: 755-764. 
Pierce, A. D., C. A. Farris, and A. H. Taylor. 2012. Use of random forests for modeling and mapping forest canopy fuels for fire behavior analysis in Lassen Volcanic National Park, California, USA. Forest Ecology and Management, v. 279, p. 77-89. 10.

Potter, B.E., 2012a. Atmospheric interactions with wildland fire behaviour - I. Basic surface interactions, vertical profiles and synoptic structures. Int. J. Wildand Fire 21, 779-801.

Robichaud, P.R. 2000. Fire effects on infiltration rates after prescribed fire in northern Rocky Mountain forests, USA. Journal of Hydrology 231-232: 220-229.

Róman-Cuesta, R.M., Gracia, M., Retana, J., 2009. Factors influencing the formation of unburned forest islands within the perimeter of a large fire. Forest Ecology and Management 258, 71-80.

Rothermel RC (1972) A mathematical model for predicting fire spread in wildland fuels. USDA Forest Service, Intermountain Forest and Range Experiment Station, Research Paper INT-115. (Ogden, UT)

Rothermel RC (1983) How to predict the spread and intensity of forest and range fires. USDA Forest Service, Intermountain Forest and Range Experiment Station, General Technical Report INT-143. (Ogden, UT)

Rothermel RC (1991) Predicting behavior and size of crown fires in the Northern Rocky Mountains. USDA Forest Service, Intermountain Research Station, Research Paper INT-438. (Ogden, UT)

Ryan, K.C., Noste, N.V., 1985. Evaluating prescribed fires. In: Lotan, J.E., Kilgore, B., Fischer, W., Mutch, R. (Tech. Coords.), Proceedings - Symposium and Workshop on Wilderness Fire. USDA Forest Service, General Technical Report INT-182, Intermountain Forest and Range Experimental Station, Ogden, UT, pp. 230-238.

Seto, D., Clements, C.B., Heilman, W.E., 2013. Turbulence spectra measured during fire front passage. Agric. Forest Meteorol. 169, 195-210Riaño, D., Chuvieco, E., Condes, S., Gonzalez-Matesanz, J., \& Ustin, S. L. (2004). Generation of crown bulk density for Pinus sylvestris L. from lidar. Remote Sensing of Environment, 92, 345-352.

Sikkink, Pamela G.; Keane, Robert E. 2012. Predicting fire severity using surface fuels and moisture. Res. Pap. RMRS-RP-96. Fort Collins, CO: U.S. Department of Agriculture, Forest Service, Rocky Mountain Research Station. $37 \mathrm{p}$

Skowronski NS, Clark KL, Duveneck M, Hom J, (2011) Three-dimensional canopy fuel loading predicted using upward and downward sensing LiDAR systems, Remote Sensing of Environment, Volume 115, Issue 2, 15 February 2011, Pages 703-714, ISSN 0034-4257

Stratton, Richard D. 2006. Guidance on spatial wildland fire analysis: models, tools, and techniques. Gen. Tech. Rep. RMRS-GTR-183. Fort Collins, CO: U.S. Department of Agriculture, Forest Service, Rocky Mountain Research Station. 15 p

Turner MG, Romme WH (1994) Landscape dynamics in crown fire ecosystems. Landsc Ecol 9: 5977. Odion, D.C., Frost, E.J., Strittholt, J.R., Jiang, H., Dellasala, D.A., Moritz, M.A., 2004. Patterns of fire severity and forest conditions in the western Klamath Mountains, California. Conservation Biology 18, 927-936.

Turner, M.G., Hargrove, W.W., Gardner, R.H., Romme, W.H., 1994. Effects of fire on landscape heterogeneity in Yellowstone National Park, Wyoming. J. Veg. Sci. 5, 731-742.

van Aardt, J. A. N., Wynne, R. H., \& Oderwald, R. G. (2006). Forest volume and biomass estimation using small-footprint Lidar-distributional parameters on a per-segment basis. Forest Science, 52(6), 636-649

Van Wagner CE (1977) Conditions for the start and spread of crown fire. Canadian Journal of Forest Research 7, 23-34. doi:10.1139/ X77-004

Vázquez de la Cueva, A., J. M. Garc'1a del Barrio, M. O. Quero, and O. S. Palomares. 2006. Recent fire regime in peninsular Spain in relation to forest potential productivity and population density. International Journal of Wildland Fire 15:397-405 
Vega J.A.; Fernández, C.; Fonturbel, T.; González-Prieto, S.; Jiménez, E., (2014), Testing the effects of straw mulching and herb seeding on soil erosion after fire in a gorse shrubland. Geoderma 223225: 79-87.

Weise, D.R., Biging, G.S., 1997. A qualitative comparison of fire spread models incorporating wind and slope effects. For. Sci. 43 (2), 170-180.

Weatherspoon, C. P., and C. N. Skinner. 1995. An assessment of factors associated with damage to tree crowns from the 1987 wildfires in northern California. Forest Science 41:430-451

Werth, Paul A.; Potter, Brian E.; Clements, Craig B.; Finney, Mark A.; Goodrick, Scott L.; Alexander, Martin E.; Cruz, Miguel G.; Forthofer, Jason A.; McAllister, Sara S. 2011. Synthesis of knowledge of extreme fire behavior: volume I for fire managers. Gen. Tech. Rep. PNW-GTR-854. Portland, OR: U.S. Department of Agriculture, Forest Service, Pacific Northwest Research Station. 144 p. 